\title{
Characterization of cattle tick fever in calves from the northwestern region of Minas Gerais, Brazil
}

\section{Caracterização do complexo da Tristeza Parasitária Bovina em bezerros da região noroeste de Minas Gerais, Brasil}

\author{
Michele Bahia1; Jullyana de Souza Silva²; Iany Santos Gontijo²; Matheus Dias Cordeiro; \\ Priscilla Nunes dos Santos ${ }^{1}$; Claudia Bezerra da Silva ${ }^{1}$; Rafael Romero Nicolino²; \\ Diego Azevedo Mota ${ }^{2}$; Jenevaldo Barbosa da Silva²; Adivaldo Henrique Fonseca ${ }^{1}$ (10) \\ ${ }^{1}$ Universidade Federal Rural do Rio de Janeiro - UFRRJ, Seropédica, RJ, Brasil \\ ${ }^{2}$ Universidade Federal dos Vales do Jequitinhonha e Mucuri - UFVJM, Unaí, MG, Brasil
}

How to cite: Bahia M, Silva JS, Gontijo IS, Cordeiro MD, Santos PN, Silva CB, et al. Characterization of cattle tick fever in calves from the northwestern region of Minas Gerais, Brazil. Braz J Vet Parasitol 2020; 29(1): e017119. http://doi.org/10.1590/S1984-29612020011

\begin{abstract}
The present study aimed to characterize the importance of the Anaplasma marginale, Babesia bovis and Babesia bigemina in the genesis of cattle tick fever (CTF) among dairy calves in the northwest of Minas Gerais, Brazil. Blood samples from 300 calves were collected, followed by DNA extraction and nested PCR using oligonucleotide primers to amplify fragments of the semi-nested for the msp5 gene (A. marginale), sbp-4 (B. bovis) and rap-1a (B. bigemina) Among the examined calves, the prevalence of A. marginale was $55.6 \%(n=167 / 300), B$. bovis was $4.0 \%(n=12 / 300)$ and $B$. bigemina was $15.3 \%$ $(n=46 / 300)$, by PCR techniques. Parasitic forms of $A$. marginale and B. bigemina were found in $36,3 \%$ and $2,6 \%$ of the blood smears while $B$. bovis was not detected. There was a statistical difference between the positivity of infected animals in the age groups 1 (10-70 days) and (>70-300 days) for A. marginale and B. bigemina. A total of 15 calves with the classic symptoms of disease were examined, and the samples obtained were confirmed as a simple infection by $A$. marginale through semi-nested PCR. These results confirm bovine anaplasmosis as the primary cause of CTF among the calves of dairy cattle within the studied area.
\end{abstract}

Keywords: Calves, tick borne diseases, hemoparasites, Brazil.

\section{Resumo}

O presente estudo teve como objetivo caracterizar a importância de Anaplasma marginale, Babesia bigemina e Babesia bovis na gênese da tristeza parasitária bovina em bezerros leiteiros do noroeste de Minas Gerais. Foram coletadas 300 amostras sanguíneas de bezerros, seguidas por extração de DNA e Nested- PCR utilizando oligonucleotídeos iniciadores que amplificam fragmentos dos genes sbp-4 (B. bovis) e rap-1a (B. bigemina) e a Semi-Nested para o gene msp5 (A. marginale). A prevalência de $A$. marginale foi $55,66 \%$ (167/300), B. bigemina, 15,33\% (46/300) e B. bovis 4,0\% (12/300) dos bezerros examinados. Formas parasitárias de $A$. marginale and $B$. bigemina foram encontradas em $36,33 \%$ e 2,66\% dos esfregaços sanguíneos, enquanto $B$. bovis não foi detectado. Houve diferença estatística entre as prevalências de animais infectados nas faixas etárias 1 (10-70 dias) e 2 (>70-300 dias). Um total de 15 animais com sintomas clássicos da doença foram examinados, e as amostras foram confirmadas como uma infecção simples por A. marginale através da Nested-PCR. Esses resultados confirmam a anaplasmose bovina como a principal agente da tristeza parasitária bovina nos bezerros do rebanho estudado.

Palavras-chaves: Bezerros, doenças transmitidas por carrapatos, hemoparasitos, Brasil. 


\section{Introduction}

The state of Minas Gerais stands out in the national context as the largest milk producer in Brazil. According to the Brazilian Institute of Statistics and Geography, the state had an estimated population of 3.4 million milked cows in 2017, with approximately 8.9 billion liters of milk being produced in Minas Gerais State (IBGE, 2017). However, tick-borne diseases are limiting factors for calf rearing among rural properties in the region (Ribeiro et al., 1984).

Cattle tick fever (CTF) is caused by a complex of frequent diseases among cattle in Brazil (Gonçalves, 2000). The agents causing this clinical manifestation include the protozoa Babesia bovis and Babesia bigemina, causing babesiosis, and rickettsia Anaplasma marginale, which causes anaplasmosis (Guglielmone, 1995). The agents responsible for bovine babesiosis in Brazil, are transmitted by the Rhipicephalus microplus tick, while the rickettsia that causes anaplasmosis can be biologically transmitted by $R$. microplus, mechanically transmitted by hematophagous arthropods such as flies and mosquitoes, fomites, and transmitted via the transplacental route (Kessler, 2001; Kocan et al., 2004; Silva et al., 2015).

When affected by anaplasmosis or babesiosis, animals exhibit clinical signs such as anorexia, shivering, tachycardia, tachypnea, reduced ruminal movements, prostration, reduced lactation, anemia, and jaundice. In the case of babesiosis may occurs hemoglobinuria and in the $B$. bovis infection, the animal may also show neurological signs, such as incoordination, staggering gait, pedal movements, and aggressiveness (Almeida et al., 2006; Costa et al., 2011; Oliveira et al., 2018; Silva et al., 2018).

In Brazil, the largest of the territory is considered of enzootic stability (Souza et al., 2000; Juliano et al., 2007; Brito et al., 2010, 2013). However, areas such as the dry region of Sergipe, dry region of Paraiba, in the central south of Paraná and extreme south of Rio Grande do Sul, are regions of enzootic instability. In this condition, younger animals possess low immunity against $A$. marginale and Babesia spp. Therefore, when they become infected at a later age, they may develop acute clinical symptomatology, which is associated with high mortality rates (Oliveira et al., 1992; Artiles et al., 1995; Marana et al., 2009; Costa et al., 2011).

The blood smear is the oldest method and is routinely used for diagnosing hemoparasites. In the acute phase of the disease, when parasitemia is high, parasites are easily detected in bovine erythrocytes (Böse et al., 1995). In carrier animals this method is less sensitive since the parasitemia is low. In this case, molecular tools using Polymerase chain reaction (PCR) increase the sensitivity (Al-Hosary, 2017).

PCR has been described as a useful tool in epidemiological studies presenting high specificity and sensitivity in the diagnosis of the etiological agents of CTF (Brito et al., 2010; Mosqueda et al., 2012; Giglioti et al., 2016; Romero-Salas et al., 2016). As such, the objective of the present study was to determine the prevalence and importance of B. bigemina, B. bovis, and A. marginale using the PCR and blood smear technique in calves from the northwestern region of Minas Gerais.

\section{Material and Methods}

\section{Compliance with ethical standards}

The present study was approved by the Council of Ethics in the Use of Animals (CEUA) of the Federal University of the Jequitinhonha and Mucuri Valleys (UFVJM) under protocol No. 060/2016. The research is in accordance with the precepts and norms of the National Council of Control of Animal Experimentation (CONCEA) in Brazil. 


\section{Sample determination}

Animals from four dairy farms located in the northwestern region of Minas Gerais state, Brazil, were randomly selected. The properties were previously selected based on reports of clinical CTF cases from the producers within the last five years. Three farms located in the municipality of Unaí (FARM A, B and C) and one rural property located in Cabeceira Grande (FARM D) were selected. The description of the location of each farm (coordinates), farm size, total number of animals per herd, number of animals evaluated per farm, age groups, and breed of herd are described in Table 1.

Table 1. Description of calves of the dairy farms evaluated from the Northwest of Minas Gerais, Brazil.

\begin{tabular}{|c|c|c|c|c|c|c|c|}
\hline Municipality & $\begin{array}{c}\text { Farm } \\
\text { (localization) }\end{array}$ & $\begin{array}{l}\text { Farm } \\
\text { Size }\end{array}$ & $\begin{array}{l}\text { Total } \\
\text { animal } \\
\text { /farm }\end{array}$ & $\begin{array}{l}\text { Animals } \\
\text { examined }\end{array}$ & $\begin{array}{c}\text { Group } 1 \\
\text { (10-70 } \\
\text { days) }\end{array}$ & $\begin{array}{c}\text { Group } 2 \\
\text { (>70-300 } \\
\text { days })\end{array}$ & $\begin{array}{l}\text { Dairy } \\
\text { breeds }\end{array}$ \\
\hline \multirow{3}{*}{ Unaí } & $\begin{array}{c}\text { Farm A } \\
16^{\circ} 06^{\prime} 46.6^{\prime \prime S} \\
47^{\circ} 05^{\prime} 49.8^{\prime \prime} \mathrm{W}\end{array}$ & $\begin{array}{c}240 \\
\text { hectares }\end{array}$ & 800 & 100 & 30 & 70 & $\begin{array}{c}\text { Dutch; Gir; } \\
\text { Jersey; } \\
\text { Crosses }\end{array}$ \\
\hline & $\begin{array}{c}\text { Farm B } \\
16^{\circ} 19^{\prime} 43.6^{\prime \prime S} \\
46^{\circ} 50^{\prime} 51.5^{\prime \prime} \mathrm{W}\end{array}$ & $\begin{array}{c}200 \\
\text { hectares }\end{array}$ & 400 & 33 & 13 & 20 & $\begin{array}{c}\text { Dutch; Gir; } \\
\text { Crosses }\end{array}$ \\
\hline & $\begin{array}{c}\text { Farm C } \\
16^{\circ} 24^{\prime} 45.2^{\prime \prime S} \\
47^{\circ} 05^{\prime} 37.5^{\prime \prime} \mathrm{W}\end{array}$ & $\begin{array}{c}300 \\
\text { hectares }\end{array}$ & 350 & 33 & 22 & 11 & $\begin{array}{c}\text { Dutch; Gir; } \\
\text { Crosses }\end{array}$ \\
\hline $\begin{array}{l}\text { Cabeceira } \\
\text { Grande }\end{array}$ & $\begin{array}{c}\text { Farm D } \\
16^{\circ} 06^{\prime} 46.6^{\prime \prime S} \\
47^{\circ} 05^{\prime} 49.8^{\prime \prime} \mathrm{W}\end{array}$ & $\begin{array}{c}450 \\
\text { hectares }\end{array}$ & 1000 & 134 & 42 & 92 & $\begin{array}{l}\text { Dutch; } \\
\text { Jersey; Kiw } \\
\text { Cross }\end{array}$ \\
\hline
\end{tabular}

The calculation of the minimum sample size was determined by the following formula: $N=p .(100-p) Z^{2} /(d . p / 100)^{2}$, where $\mathrm{N}=$ number of samples; $\mathrm{p}=$ expected prevalence; $\mathrm{Z}=$ trust rating; $\mathrm{d}=$ margin of error. The expected prevalence of $50 \%$ for CTF agents was estimated by a previous pilot. The confidence interval was $95 \%$ and the margin of error was 5\%. Thus, the required sample size was at least 196 animals.

\section{Animals}

The analyzed herds comprised of several dairy breeds (Dutch, Gir, Jersey, Kiwi Cross and their crosses). Visits to the properties were conducted between January and September 2017. The evaluated animals were randomly selected according to the availability of the property. Two groups of calves were evaluated in the present study. Group 1 with animals aged 10 to 70 days and group 2 with animals older than 70 to 300 days.

Following the management adopted in each one of the properties, in Group 1 (10-70 days) all animals received colostrum in the first three days following birth, and subsequent suckling was performed through a baby bottle and individual buckets. In addition to milk, all calves received Tifton grass (Cynodon spp.) hay and concentrated rations for calves. Weaning of the animals was performed by body weight (i.e. when the animals reached a body weight between $70 \mathrm{~kg}$ and $100 \mathrm{~kg}$ ), varying with the breeds of the animals. The Group 2 (> 70 - 300 days), consisted of weaned animals kept in Brachiaria brizantha grass, receiving corn silage and concentrated feed for heifers in troughs. These animals presented weights ranging from $100 \mathrm{~kg}$ to $220 \mathrm{~kg}$ according to the racial pattern. During the collection of biological samples, the animals were inspected for the presence of ectoparasites. Herds were vaccinated against brucellosis, foot-and-mouth disease (FMD), clostridiosis, rabies and Bovine Viral Diarrhea (BVD). 


\section{Sample collections and blood smear}

Blood samples were collected from 300 calves of both sexes of group $1(n=107)$ and group $2(n=193)$. Sample collection were collected into tubes with anticoagulant ethylenediamine tetraacetic acid (EDTA) for subsequent extraction of DNA to perform the PCR. Blood smears were prepared, fixed with methanol, stained with Giemsa and microscopically observed for the detection of A. marginale and Babesia spp. in blood.

\section{DNA Extraction}

DNA extraction from whole blood was performed using the Wizard Genomic DNA Purification Kit (Promega, USA) according to the manufacturer's recommendations. The extracted DNA was quantified and stored in $100 \mu \mathrm{L}$ aliquots in a freezer at $-20^{\circ} \mathrm{C}$ for subsequent PCR.

\section{Molecular detection of $A$. marginale, $B$. bovis, and B. bigemina}

Molecular diagnosis for $A$. marginale was performed using the semi-nested PCR technique for the msp5 gene standardized by (Torioni De Echaide et al., 1998). According to the method of (Terkawi et al., 2011), nested PCR was adopted to amplify the fragments of sbp-4 and rap-1a genes of $B$. bovis and B. bigemina, respectively. The primers used for the CTF agents as well as the sizes of amplified fragments are presented in Table 2.

Table 2. Primer sets specific for A. marginale $m s p 5$, B. bovis sbp-4 and B. bigemina rap-1a genes using for molecular assays.

\begin{tabular}{|c|c|c|c|c|}
\hline Genes & Etiological agent & Assays & Oligonucleotide primers & $\begin{array}{c}\text { Product } \\
\text { sizes }\end{array}$ \\
\hline \multirow[t]{4}{*}{ msp5 } & \multirow[t]{4}{*}{ A. marginale } & \multirow[t]{2}{*}{ PCR } & 5- GCATAGCCTCCGCGTCTTTC-3 & \multirow{2}{*}{$457 \mathrm{bp}$} \\
\hline & & & 5 -TCCTCGCCTTGGCCCTCAGA-3 & \\
\hline & & \multirow[t]{2}{*}{ SnPCR } & 5 -TACACGTGCCCTACCGAGTTA-3 & \multirow{2}{*}{$344 \mathrm{bp}$} \\
\hline & & & 5 -TCCTCGCCTTGGCCCTCAGA-3 & \\
\hline \multirow[t]{4}{*}{$s b p-4$} & \multirow[t]{4}{*}{ B. bovis } & \multirow[t]{2}{*}{ PCR } & 5-AGTTGTTGGAGGAGGCTAAT-3 & \multirow{2}{*}{907 bp } \\
\hline & & & 5 -TCCTTCTCGGCGTCCTTTTC-3 & \\
\hline & & \multirow[t]{2}{*}{$\mathrm{nPCR}$} & 5 -GAAATCCCTGTTCCAGAG-3 & \multirow{2}{*}{$503 \mathrm{bp}$} \\
\hline & & & 5 -TCGTTGATAACACTGCAA-3 & \\
\hline \multirow[t]{4}{*}{ rap-1a } & \multirow[t]{4}{*}{ B. bigemina } & \multirow[t]{2}{*}{ PCR } & 5-GAGTCTGCCAAATCCTTAC-3 & \multirow{2}{*}{$879 \mathrm{bp}$} \\
\hline & & & 5-TCCTCTACAGCTGCTTCG-3 & \\
\hline & & \multirow[t]{2}{*}{$\mathrm{nPCR}$} & 5-AGCTTGCTTTCACAACTCGCC-3 & \multirow{2}{*}{$412 b p$} \\
\hline & & & 5-TTGGTGCTTTGACCGACGACAT-3 & \\
\hline
\end{tabular}

PCR: Polimerase Chain Reaction; snPCR: semi-nested Polimerase Chain Reaction; nPCR: nested Polimerase Chain Reaction; bp: base pairs.

PCR products were analyzed by $1.5 \%$ agarose gel electrophoresis. For each reaction, a positive control and two negative controls (ultrapure water, HyPure ${ }^{\mathrm{TM}}$ Molecular Biology) were included. Positive controls were obtained from the blood of naturally infected cattle from the municipality of Seropédica, Rio de Janeiro, Brazil. 


\section{Statistical analysis}

The frequencies of $A$. marginale, $B$. bovis, and $B$. bigemina positive animals between the group 1 (10-70 days) and group 2 (> 70-300 days) were compared by Fisher's exact or Chi-square test, with a confidence level of $95 \%$. Statistical operations were performed with the aid of the statistical package $R$ Foundation for Statistical Computing, version 3.6.2 (2019). The frequencies of $A$. marginale, $B$. bigemina and $B$. bovis positive animals between the farms were done by variance analyze (ANOVA) with $95 \%$ confidence level.

\section{Results}

Among examined animals, the prevalence of $A$. marginale was $55.66 \%$, $B$. bigemina was $15.33 \%$, and $B$. bovis was $4.0 \%$ by PCR. Parasitic forms of $A$. marginale and $B$. bigemina were found in $36,33 \%$ and $2,66 \%$ of the blood smears while $B$. bovis was not detected (Table 3 ).

Table 3. Prevalence of agents Anaplasma marginale, Babesia bovis, and Babesia bigemina in 300 calves from the Northwest of Minas Gerais, Brazil.

\begin{tabular}{ccccccc}
\hline \multirow{2}{*}{ Municipality } & \multicolumn{2}{c}{$\boldsymbol{A . \text { marginale }}$} & \multicolumn{2}{c}{ B. bigemina } & \multicolumn{2}{c}{ B. bovis } \\
\cline { 2 - 7 } & snPCR & $\begin{array}{c}\text { Blood } \\
\text { smear }\end{array}$ & nPCR & $\begin{array}{c}\text { Blood } \\
\text { smear }\end{array}$ & nPCR & $\begin{array}{c}\text { Blood } \\
\text { smear }\end{array}$ \\
\hline Cabeceira Grande & $42.53 \%$ & $28.86 \%$ & $12.68 \%$ & $2.98 \%$ & $4.0 \%$ & $0 \%$ \\
Unaí & $66.26 \%$ & $43.97 \%$ & $17.46 \%$ & $2.40 \%$ & $6.62 \%$ & $0 \%$ \\
Total & $55.66 \%$ & $36.33 \%$ & $15.33 \%$ & $2.66 \%$ & $4.0 \%$ & $0 \%$ \\
\hline
\end{tabular}

Sn PCR - Semi nested PCR; nPCR - nested PCR.

The frequencies of CTF agent infections on each farm are shown in table 4. No statistical differences were found between the properties for $A$. marginale ( $p$-value: 0.0521) B. bigemina ( $\mathrm{p}$-value: 0.6388 ) and B. bovis ( $\mathrm{p}$-value: 0.7760 ).

Table 4. Prevalence of agents Anaplasma marginale, Babesia bigemina and Babesia bovis in calves of dairy farm in the Northwest of Minas Gerais, Brazil.

\begin{tabular}{ccccc}
\hline Municipality & $\begin{array}{c}\text { Farm } \\
\text { identification }\end{array}$ & A. marginale & B. bigemina & B. bovis \\
\hline \multirow{2}{*}{ Unaí } & A & $54.00 \%(54 / 100)$ & $1.2 \%(12 / 100)$ & $6.0 \%(06 / 100)$ \\
& B & $90.90 \%(30 / 33)$ & $15.15 \%(05 / 33)$ & $6.06 \%(02 / 33)$ \\
Cabeceira Grande & C & $78.78 \%(26 / 33)$ & $36.36 \%(12 / 33)$ & $9.09 \%(03 / 33)$ \\
$p$ - value & D & $42.53 \%(57 / 134)$ & $12.68 \%(17 / 134)$ & $0.74 \%(01 / 134)$ \\
\hline
\end{tabular}

Infection rates in the group 1 of calves were $41.12 \%, 26.16 \%$, and $3.73 \%$ for $A$. marginale, B. bigemina, and B. bovis, respectively, while in the group 2, the prevalence was $63.73 \%$, $9.32 \%$, and $4.14 \%$ for the agents, correspondingly. A statistical difference was observed for A. marginale ( $\mathrm{p}$-value:0.0002575) and B. bigemina ( $\mathrm{p}$-value: 0.0002065$)$ infection, while for $B$. bovis there was no difference ( $\mathrm{p}$-value: 1$)$.

A total of 15 animals with clinical suspicion of CTF were examined at the time of site visits, and infection was confirmed only by $A$. marginale. Five animals were from Unaí (Farm A), while the teen animals were farm D from Cabeceira Grande. During the 
inspection of the calves of each property observed ticks and blood flies (Horn fly, Stable fly), and according to farmers in periods of higher rainfall tabanids are observed.

The sick animals belonged to group 2 of the properties, with an age range of 70 to 300 days. Calves with anaplasmosis presented mainly fever, weight loss, pale mucosae and jundaice.

The producers reported that animals affected by the disease were commonly treated with several drugs, such as oxytetracycline at a concentration of $20 \mathrm{mg} / \mathrm{kg}$ and imidocarb dipropionate at $2.1 \mathrm{mg} / \mathrm{kg}$ predominating. Ivermectin application, at $1 \mathrm{mg} / \mathrm{kg}$ and bathing with the contact product COLOSSO PULVERIZAÇÃO ${ }^{\circledR}$ (cypermethrin 15.0 g, chlorpyrifos 25.0 $\mathrm{g}$, and citronellal $1.0 \mathrm{~g}$, Ouro Fino, Brazil), and a pour-on application of the systemic product FLUAZURON ${ }^{\circledR}$ (fluazuron $3.00 \mathrm{~g}$ and abamectin $0.50 \mathrm{~g}$, Ouro Fino, Brazil).

\section{Discussion}

The frequency of positive for agents of CTF animals in PCR was higher than in blood smear. No parasitic forms of B. bovis were found in the blood smear. Fahrimal et al. (1992) reports that it is difficult to detect $B$. bovis infected carrier animals in the blood smear due to the low concentration of parasites present in the peripheral blood. According to Böse et al. (1995) the PCR technique is 100 times more sensitive than the blood smear technique, being indicated for the detection of animals with low parasitemia.

Higher infection rates of $A$. marginale than Babesia spp. were observed in the present study, although they have the same $R$. microplus biological vector, the intensive use of acaricides may be reducing the transmission rate of protozoa in the region.

As an important epidemiological factor for the establishment of higher prevalence of A. marginale is the persistence of reservoir infection. Consequently, Mechanical vectors (hematophagous flies and mosquitoes), fomites (surgical material and vaccination) may contribute to increased regional spread of $A$. marginale in herd. (Kessler, 2001; Reinbold et al., 2010; Silva et al., 2015).

Our results differ from previous studies that obtained prevalence values of 98.6 and $95.1 \%$ for $A$. marginale and B. bovis, respectively, in the state of Rondônia, in the Brazilian Amazon (Brito et al., 2010, 2013). In this study, the authors observed prevalence values of $76.2 \%$, $52.5 \%$, and $33.2 \%$ for $A$. marginale, B. bigemina, and B. bovis, respectively, in the Piauí dairy basin-an area of enzootic stability for rickettsia and enzootic instability for Babesia spp. Notably, (Jaimes-Dueñez et al., 2017) observed infection rates of 59.3\%, 31.5\%, and 13.8\% for $A$. marginale, B. bigemina, and B. bovis, respectively, in cattle in Colombia, results which are similar to those described in the present study.

It was observed that calves from the group 2 had a higher prevalence of $A$. marginale infection, thus corroborating with authors who associate the increase in age with an increase in CTF prevalence (Ibrahim et al., 2013; Silva et al., 2015; Abdela et al., 2018). Low frequency of $B$. bigemina infection was observed in the same group. The use intensive of acaricides can be interfered on lower protozoan transmission rates.

The lower prevalence of Anaplasma infection in younger animals can be attributed to restricted grazing which reduces the probability of contact with vectors (hematophagous flies and ticks). In addition, the lower prevalence detected in young animals can be attributed to passive immunity transmitted during colostrum ingestion (Abdela et al., 2018). In addition, the tick life stage influences the transmission dynamics of Babesia spp. Since $B$. bovis and B. bigemina are transmitted by $R$. microplus larvae and nymphs, respectively (Bock et al., 2004), the degree of infestation of these stages in animals may have fluctuated over the months on the farms of northwestern Minas Gerais, thus affecting infection rates in the groups of calves.

Corroborating these results, Melo et al. (2001) found that over $90 \%$ of calves possessed antibodies against $A$. marginale within the first month of life, with these values dropping to a minimum of $13.6 \%$ from three to five months. However, due to the first infection, over $96 \%$ from six months of age were positive again due to acquired immunity. 
The present results corroborate with other studies where the prevalence of clinical disease was primarily associated with simple infection by $A$. marginale (Gonçalves et al., 2011; Costa et al., 2011; Amorim et al., 2014). Botucatu, a city in São Paulo state, was part of a retrospective study of CTF cases from 1987 to 2007 in crossbred calves up to one year old, and $A$. marginale was the main agent of the disease, which caused regional economic losses (Gonçalves et al., 2011). In the northeast of Brazil, Costa et al. (2011) described the occurrence of 24 outbreaks in the interior of Paraiba, with 75\% of cases being associated with simple infection by $A$. marginale, while (Amorim et al., 2014) detected A. marginale as the main agent found in CTF within the southern region of Bahia. The higher frequency of clinical anaplasmosis cases may also be associated with the broad genetic diversity of A. marginale, and studies report different pathogenic strains involved in disease outbreaks among cattle herds in the Americas (Almazán et al., 2008; Ruybal et al., 2009; Machado et al., 2015; Silva et al., 2015).

In the dairy farms studied, the reports are on clinical cases of anaplasmosis in animals of group 2 with age of 70 to 300 days. According to Zabel et al. (2018), anaplasmosis is most commonly observed in cattle over one year of age. In addition, cows in the final third of gestation and/or lactation may exhibit a immunosuppression and signs of acute anaplasmosis (Aktas \& Özübek, 2017). However, the super acute anaplasmosis characterized by a high mortality rate within a few hours of the development of clinical signs is more frequently observed in dairy breeds (Abba et al., 2016).

Low rates of infection by $B$. bigemina and $B$. bovis were observed in calves from farms of the northwestern of Minas Gerais. Babesiosis outbreaks with high mortality rates have been described related to the transfer of animals from areas of instability to zones of enzootic stability where climatic conditions, farm management and intensive use of acaricides interfered in the development of the vector tick (Schild et al., 2008; Hue et al., 2013; Oliveira et al., 2018) In these case the vaccination has been an important method for preventing babesiosis outbreaks (Gohil et al., 2013).

The properties analyzed in the present study used drugs based on oxytetracycline and imidocarb dipropionate, and both drugs are effective in the treatment of bovine anaplasmosis. Following clinical recovery from the disease, animals remain carriers of the agent; thus, different protocols made with both drugs were not effective for the chemical sterilization of Anaplasma (Coetzee et al., 2005, 2006; Alberton et al., 2015). The recommended treatment protocols used were based only on imidocarb dipropionate for the treatment of CTF in the Northwest region of Minas Gerais state, and are inappropriate due to inefficiency in the treatment of bovine anaplasmosis. In this context, it is recommended to conduct an adequate diagnosis and adapt the treatments for tetracycline or oxytetracycline-based medicinal products. In addition, according to Doyle et al. (2007), imidocarb dipropionate has adverse effects such as salivation, tearing, tachypnea, and pain at the site of injection, and is more commonly used in association with Babesia spp. infection with A. marginale.

\section{Conclusion}

The agents of CTF infect calves in the Northwest region of Minas Gerais, Brazil. As such, treatment protocols adopted in this region should be recommended based on an adequate diagnosis, prioritizing the insertion of broad-spectrum antibiotics that are effective against bacterial infections due to the occurrence of $A$. marginale.

\section{Acknowledgement}

We would like to express our gratitude to the Conselho Nacional de Desenvolvimento Científico e Tecnológico - CNPq (A.H.F. 305480/2013-8), Coordenação de Apoio ao Aperfeiçoamento de Pessoal de Nível Superior - CAPES (M.B. 2015250223) and Fundação 
de Apoio à pesquisa no estado do Rio de Janeiro - FAPERJ (A.H.F., grant number E 26/201.144/2014), for their financial support.

\section{References}

Abba Y, Jesse FFA, Sadiq MA, Ibrahim HH, Chung ELT, Bitrus AA, et al. Clinical management and gross pathological findings of a severe anaplamosis in a dairy cow. J Adv Vet Anim Res 2016; 3(2): 195199. http://dx.doi.org/10.5455/javar.2016.c150.

Abdela N, Ibrahim N, Begna F. Prevalence, risk factors and vectors identification of bovine anaplasmosis and babesiosis in and around Jimma town, Southwestern Ethiopia. Acta Trop 2018; 177: 9-18. http://dx.doi.org/10.1016/j.actatropica.2017.09.010. PMid:28939494.

Aktas M, Özübek S. Outbreak of anaplasmosis associated with novel genetic variants of Anaplasma marginale in a dairy cattle. Comp Immunol Microbiol Infect Dis 2017; 54: 20-26. http://dx.doi.org/10.1016/j.cimid.2017.07.008. PMid:28915997.

Al-Hosary AAT. Comparison between conventional and molecular methods for diagnosis of bovine babesiosis (Babesia bovis infection) in tick infested cattle in upper Egypt. J Parasit Dis 2017; 41(1): 243-246. http://dx.doi.org/10.1007/s12639-016-0785-2. PMid:28316419.

Alberton LR, Orlandini CF, Zampieri TM, Nakamura AY, Gonçalves DD, Piau R Jr, et al. Efficacy of imidocarb dipropionate, enrofloxacin and oxytetracycline chlorydrate on the treatment of cattle naturally infected by Anaplasma marginale. Arq Bras Med Vet Zootec 2015; 67(4): 1056-1062. http://dx.doi.org/10.1590/1678-4162-7999.

Almazán C, Medrano C, Ortiz M, de la Fuente J. Genetic diversity of Anaplasma marginale strains from an outbreak of bovine anaplasmosis in an endemic area. Vet Parasito/ 2008; 158(1-2): 103-109. http://dx.doi.org/10.1016/j.vetpar.2008.08.015. PMid:18842342.

Almeida MB, Tortelli FP, Riet-Correa B, Ferreira JLM, Soares MP, Farias NAR, et al. Tristeza parasitária bovina na região sul do Rio Grande do Sul: estudo retrospectivo de 1978-2005. Pesq Vet Bras 2006; 26(4): 237-242. http://dx.doi.org/10.1590/S0100-736X2006000400008.

Amorim LS, Wenceslau AA, Carvalho FS, Carneiro PLS, Albuquerque GR. Bovine babesiosis and anaplasmosis complex: diagnosis and evaluation of the risk factors from Bahia, Brazil. Rev Bras Parasitol Vet 2014; 23(3): 328-336. http://dx.doi.org/10.1590/S1984-29612014064. PMid:25271452.

Artiles J, Alves-Branco FPJ, Martins JR, Correa LB, Sapper MFM. Prevalência de Babesia bovis, Babesia bigemina e Anaplasma marginale no município de Bagé, RS. Rev Bras Parasitol Vet 1995; 4(Suppl. 1): 179.

Bock R, Jackson L, de Vos A, Jorgensen W. Babesiosis of cattle. Parasitology 2004;129(S1 Suppl.): S247-S269. http://dx.doi.org/10.1017/S0031182004005190. PMid:15938514.

Böse R, Jorgensen WK, Dalgliesh RJ, Friedhoff KT, de Vos AJ. Current state and future trends in the diagnosis of babesiosis. Vet Parasitol 1995; 57(1-3): 61-74. http://dx.doi.org/10.1016/03044017(94)03111-9. PMid:7597794.

Brito LG, Oliveira MCS, Rocha RB, Netto FGS, Marim AD, Souza GCR, et al. Anaplasma marginale infection in cattle from south-western Amazonia. Pesq Vet Bras 2010; 30(3): 249-254. http://dx.doi.org/10.1590/S0100-736X2010000300011.

Brito LG, Rocha RB, Barbieri FS, Ribeiro ES, Vendrami FB, Souza GCR, et al. Babesia bovis infection in cattle in the southwestern Brazilian Amazon. Ticks Tick Borne Dis 2013; 4(1-2): 78-82. http://dx.doi.org/10.1016/j.ttbdis.2012.08.001. PMid:23312480.

Coetzee JF, Apley MD, Kocan KM, Rurangirwa FR, Van Donkersgoed J. Comparison of three oxytetracycline regimens for the treatment of persistent Anaplasma marginale infections in beef cattle. Vet Parasitol 2005; 127(1): 61-73. http://dx.doi.org/10.1016/j.vetpar.2004.08.017. PMid:15675047.

Coetzee JF, Apley MD, Kocan KM. Comparison of the efficacy of enrofloxacin, imidocarb, and oxytetracycline for clearance of persistent Anaplasma marginale infections in cattle. Vet Ther 2006; 7(4): 347360. PMid:17216590. 
Costa VM, Rodrigues AL, Medeiros JM, Labruna MB, Simões SV, Riet-Correa F. Tristeza parasitária bovina no Sertão da Paraíba. Pesq Vet Bras 2011; 31(3): 239-243. http://dx.doi.org/10.1590/S0100-736X2011000300009.

Doyle RL, Silva AS, Monteiro SG, Santurio JM, Graça DL. Eficácia de medicamentos no controle da infecção experimental por Trypanosoma evansi em ratos. Acta Sci Vet 2007; 35(1): 67-71. http://dx.doi.org/10.22456/1679-9216.15817.

Fahrimal Y, Goff WL, Jasmer DP. Detection of Babesia bovis carrier cattle by using polymerase chain reaction amplification of parasite DNA. J Clin Microbiol 1992; 30(6): 1374-1379.

Giglioti R, Oliveira HN, Santana CH, Ibelli AMG, Néo TA, Bilhassi TB, et al. Babesia bovis and Babesia bigemina infection levels estimated by qPCR in Angus cattle from an endemic area of São Paulo state, Brazil. Ticks Tick Borne Dis 2016; 7(5): 657-662. http://dx.doi.org/10.1016/j.ttbdis.2016.02.011. PMid:26907097.

Gohil S, Herrmann S, Günther S, Cooke BM. Bovine babesiosis in the 21st century: advances in biology and functional genomics. Int J Parasitol 2013; 43(2): 125-132. http://dx.doi.org/10.1016/j.ijpara.2012.09.008. PMid:23068911.

Gonçalves PM. Epidemiologia e controle da tristeza parasitária bovina na região sudeste do Brasil. Cienc Rural 2000; 30(1): 187-194. http://dx.doi.org/10.1590/S0103-84782000000100030.

Gonçalves RC, Silva AA, Ferreira DOL, Chiacchio SB, Lopes RS, Borges AS, et al. Tristeza Parasitária em bovinos na região de Botucatu-SP: estudo retrospectivo de 1986-2007. Semina: Ciênc Agrár 2011; 32(1): 307-312. http://dx.doi.org/10.5433/1679-0359.2011v32n1 p307.

Guglielmone AA. Epidemiology of babesiosis and anaplasmosis in South and Central America. Vet Parasitol 1995; 57(1-3): 109-119. http://dx.doi.org/10.1016/0304-4017(94)03115-D. PMid:7597777.

Hue T, Graille M, Mortelecque A, Desoutter D, Delathiere JM, Marchal C, et al. Diagnostic methods used to monitor an outbreak of babesiosis (Babesia bovis) in a herd of feral cattle in New Caledonia. Aust Vet J 2013; 91(6): 254-258. http://dx.doi.org/10.1111/avj.12059. PMid:23718796.

Ibrahim HM, Adjou Moumouni PF, Mohammed-Geba K, Sheir SK, Hashem IS, Cao S, et al. Molecular and serological prevalence of Babesia bigemina and Babesia bovis in cattle and water buffalos under small-scale dairy farming in Beheira and Faiyum Provinces, Egypt. Vet Parasitol 2013; 198(1-2): 187-192. http://dx.doi.org/10.1016/j.vetpar.2013.08.028. PMid:24075417.

Instituto Brasileiro de Geografia e Estatística - IBGE. Diretoria de Pesquisas e Coordenação de Agropecuária. Produção da Pecuária Municipal 2017 [online]. Brasília: IBGE; 2017. [cited 2019 Feb 06]. Available from: https://www.ibge.gov.br/estatisticas-novoportal/economicas/agriculturaepecuaria/9107-producao-dapecuaria-municipal.html

Jaimes-Dueñez J, Triana-Chávez O, Mejía-Jaramillo AM. Parasitological and molecular surveys reveal high rates of infection with vector-borne pathogens and clinical anemia signs associated with infection in cattle from two important livestock areas in Colombia. Ticks Tick Borne Dis 2017; 8(2): 290-299. http://dx.doi.org/10.1016/j.ttbdis.2016.12.002. PMid:27956049.

Juliano RS, Machado RZ, Fioravanti MC, Andrade GM, Jayme VS. Soroepidemiologia da babesiose em rebanho de bovinos da raça Curraleiro. Cienc Rural 2007; 37(5): 1387-1392. http://dx.doi.org/10.1590/S0103-84782007000500026.

Kessler RH. Considerações sobre a transmissão de Anaplasma marginale. Pesq Vet Bras 2001; 21(4): 177-179. http://dx.doi.org/10.1590/S0100-736X2001000400009.

Kocan KM, de la Fuente J, Blouin EF, Garcia-Garcia JC. Anaplasma marginale (Rickettsiales: Anaplasmataceae): recent advances in defining host-pathogen adaptations of a tick-borne rickettsia. Parasitol. 2004;129(S1 Suppl. 1): S285-S300. http://dx.doi.org/10.1017/S0031182003004700. PMid:15938516.

Machado RZ, Silva JB, André MR, Gonçalves LR, Matos CA, Obregón D. Outbreak of anaplasmosis associated with the presence of different Anaplasma marginale strains in dairy cattle in the states of São Paulo and Goiás, Brazil. Rev Bras Parasitol Vet 2015; 24(4): 438-446. http://dx.doi.org/10.1590/S1984-29612015078. PMid:26648009.

Marana ERM, Dias JA, Freire RL, Vicentini JC, Vidotto MC, Vidotto O. Soroprevalência de Anaplasma marginale em bovinos da região Centro-Sul do estado do Paraná, Brasil, por um teste 
imunoenzimático competitivo utilizando proteína recombinante MSP5-PR1. Rev Bras Parasitol Vet 2009; 18(1): 20-26. http://dx.doi.org/10.4322/rbpv.01801004. PMid:19500456.

Melo VSP, Passos LMF, Facury-Filho EJ, Saturnino HM, Ribeiro MFB. Natural infection of calves by Anaplasma marginale in dairy herds of the Metalúrgica Region, Minas Gerais. Pesq Vet Bras 2001; 21(4): 146-150. http://dx.doi.org/10.1590/S0100-736X2001000400004.

Mosqueda J, Olvera-Ramirez A, Aguilar-Tipacamu G, Canto GJ. Current advances in detection and treatment of babesiosis. Curr Med Chem 2012; 19(10): 1504-1518. http://dx.doi.org/10.2174/092986712799828355. PMid:22360483.

Oliveira AA, Pedreira PAS, Almeida MFRS. Doenças de bezerros. II. Epidemiologia da anaplasmose no estado de Sergipe. Arq Bras Med Vet Zootec 1992; 44(5): 377-386.

Oliveira PA, Alves DM, Zamboni R, Scheid HV, Alberti TS, Marcolongo-Pereira C, et al. Babesiose cerebral em bezerros. Pesq Vet Bras 2018; 38(5): 832-834. http://dx.doi.org/10.1590/1678-5150pvb-5424.

Reinbold JB, Coetzee JF, Sirigireddy KR, Ganta RR. Detection of Anaplasma marginale and A. phagocytophilum in bovine peripheral blood samples by duplex real-time reverse transcriptase PCR assay. J Clin Microbiol 2010; 48(7): 2424-2432. http://dx.doi.org/10.1128/JCM.02405-09. PMid:20463162.

Ribeiro M, Patarroyo JHS, Santos JL, Farias JE. Epidemiologia da anaplasmose bovina no estado de Minas Gerais. I. Prevalência de anticorpos aglutinantes e fluorescentes na Zona da Mata. Arq Bras Med Vet Zootec 1984; 36(4): 425-432.

Romero-Salas D, Mira A, Mosqueda J, García-Vázquez Z, Hidalgo-Ruiz M, Vela NAO, et al. Molecular and serological detection of Babesia bovis- and Babesia bigemina-infection in bovines and water buffaloes raised jointly in an endemic field. Vet Parasitol 2016; 217: 101-107. http://dx.doi.org/10.1016/j.vetpar.2015.12.030. PMid:26827869.

Ruybal P, Moretta R, Perez A, Petrigh R, Zimmer P, Alcaraz E, et al. Genetic diversity of Anaplasma marginale in Argentina. Vet Parasitol 2009; 162(1-2): 176-180. http://dx.doi.org/10.1016/j.vetpar.2009.02.006. PMid:19285808.

Schild AL, Ruas JL, Farias NA, Grecco FB, Soares MP. Aspectos epidemiológicos de um surto de babesiose cerebral em bovinos em zona livre de carrapato. Cienc Rural 2008; 38(9): 2646-2649. http://dx.doi.org/10.1590/S0103-84782008000900041.

Silva JB, Goncalves LR, Varani AM, Andre MR, Machado RZ. Genetic diversity and molecular phylogeny of Anaplasma marginale studied longitudinally under natural transmission conditions in Rio de Janeiro, Brazil. Ticks Tick Borne Dis 2015; 6(4): 499-507. http://dx.doi.org/10.1016/j.ttbdis.2015.04.002. PMid:25985719.

Silva TM, Areco WVC, Faccin TC, Melo SMP, Fighera RA, Kommers GD. Caracterização histoquímica no diagnóstico da babesiose bovina por Babesia bovis. Pesq Vet Bras 2018; 38(4): 649-658. http://dx.doi.org/10.1590/1678-5150-pvb-5254.

Souza JCP, Soares CO, Massard CL, Scofield A, Fonseca AH. Soroprevalência de Anaplasma marginale em bovinos na mesorregião Norte Fluminense. Pesq Vet Bras 2000; 20(3): 97-101. http://dx.doi.org/10.1590/S0100-736X2000000300002.

Terkawi MA, Huyen NX, Shinuo C, Inpankaew T, Maklon K, Aboulaila M, et al. Molecular and serological prevalence of Babesia bovis and Babesia bigemina in water buffaloes in the northeast region of Thailand. Vet Parasitol 2011; 178(3-4): 201-207. http://dx.doi.org/10.1016/j.vetpar.2011.01.041. PMid:21324601.

Torioni de Echaide S, Knowles DP, McGuire TC, Palmer GH, Suarez CE, McElwain TF. Detection of cattle naturally infected with Anaplasma marginale in a region of endemicity by nested PCR and a competitive enzyme- linked immunosorbent assay using recombinant major surface protein 5. J Clin Microbiol 1998; 36(3): 777-782. http://dx.doi.org/10.1128/JCM.36.3.777-782.1998. PMid:9508311.

Zabel TA, Agusto FB. Transmission dynamics of bovine anaplasmosis in a Cattle Herd. Interdiscip Perspect Infect Dis 2018; 2018: 1-16. http://dx.doi.org/10.1155/2018/4373981. PMid:29853873. 